\title{
COMPARING SURFACE CARBON CONCENTRATIONS AND CERTAIN PARAMETERS OF THE SOILS ON WHICH MEDICINAL AND AROMATIC PLANTS GROW
}

\author{
ÇELIK, A. ${ }^{1 *}-$ SAKİN, E. ${ }^{2}$ \\ ${ }^{1}$ University of Adiyaman, Vocational Schools in Kahta, Plant and Animal Production \\ Department, 02400, Adiyaman, Turkey.E-mail: ahmetcelik@adiyaman.edu.tr \\ ${ }^{2}$ Department of Soil Science and Plant Nutrient of Agriculture, Faculty of Harran University, \\ Şanliurfa,Turkey.esakin@harran.edu.tr \\ *Corresponding author \\ e-mail:ahmetcelik@adiyaman.edu.tr; \\ phone: +904167258150; fax: +904167257792
}

(Received $5^{\text {th }}$ Dec 2016; accepted 21 ${ }^{\text {st }}$ Mar 2017)

\begin{abstract}
Organic carbon is one of the common indicators used in studies on global climate change for major problems of land degradation, desertification and biodiversity decrease. Carbon as one of the absolute necessary element is indispensable for survival of all living beings. Soils are carbon sources for the land as well as the atmosphere. For that reason, surface carbon amounts and certain parameters were analyzed in this study for the soils in which medicinal and aromatic plants are grown. In this study, physical and chemical analyses were carried out in disturbed soil samples which were taken out at two different depths from totally 60 points in areas with three different medicinal and aromatic plants (Rosmarinus officinalis, Salvia officinalis, Origanum onites) found in Adiyaman-Kahta district. The soils in the study area were determined to have no drainage problem, with clay and clay-loam texture (37.27\%), low alkali $\mathrm{pH}$ (7.67), to be saline-alkaline (EC: $0.31 \mathrm{dS} \mathrm{m}^{-1}$ ), to have very low calcareous content $(1.11 \%)$ and medium-level organic matter $(2.13 \%)$. In terms of nutritional elements, it was determined that there were very low nitrogen $(\mathrm{N})(0.07 \%)$, some phosphorus $(\mathrm{P})\left(4.28 \mathrm{~kg} \mathrm{da}^{-1}\right)$ and zinc $(\mathrm{Zn})(0.54 \mathrm{ppm})$, high potassium $(\mathrm{K})\left(157.39 \mathrm{~kg} \mathrm{da}^{-1}\right)$ and iron $(\mathrm{Fe})(5.31 \mathrm{ppm})$, and adequate amount of copper $(\mathrm{Cu})(2.13 \mathrm{ppm})$ and manganese $(\mathrm{Mn})(5.98 \mathrm{ppm})$. Organic carbon concentration of the soils was between 2.42 and $5.05 \mathrm{~kg} \mathrm{~m}^{-2}$, and determined to be $3.76 \mathrm{~kg} \mathrm{C} \mathrm{m}^{-2}$ as mean. Inorganic carbon concentrations varied between 2.75 and $5.36 \mathrm{~kg} \mathrm{~m}^{-2}$, and determined to be $4.08 \mathrm{~kg} \mathrm{~m}^{-2}$ on mean. In this case, the highest organic and inorganic carbon concentrations in the study area were found to be in areas where sage (Salvia officinalis) plant grew.
\end{abstract}

Keywords: biodiversity, organic carbon, Kahta, land degradation, organic matter

\section{Introduction}

Scientific and technological improvements have gained momentum during the process following the industrial revolution. There is no question that these revolutions and developments have significantly improved the quality of life of the humanity on many areas. On the other hand, these revolutions and advancements have increased the demand for goods and services on the entire world economies drastically as well. As a natural result of this global economic growth, today high consumption trends in societies pose great threats to natural living beings in the ecosystem on the entire planet. Under such realities, production capability and sustainably maintaining soil productivity are high priority concerns in determining the land use quality of soils in agricultural applications. 
Today climate change appears as one of the major problems impacting the agricultural production that decreased significantly in recent years. Moreover, soil pollution caused by droughts and improper agricultural implementations have deteriorated the affluence of soils and caused losses of mineral rich soils. In conclusion, soil organic carbon that prevents erosion through the aggregate formation and increases the nutritional element utility through the water holding capacity of the soils decreases below $2 \%$ as the critical level. The ideal value has been mentioned to be $5 \%$ by European Soil Bureau.

The cycle of carbon between atmosphere, biosphere, hydrosphere and geosphere is called carbon cycle. In other words, this is a bio-geo-chemical events' chain (Schlesinger and Andrews, 2000). In the nature, there are five (5) main carbon pools as (i) Ocean, (ii) Geological, (iii) Soil, (iv) Biotic, and (v) Atmospheric. All these pools are correlated with each other through a carbon cycle. The ocean pool is estimated approximately to be $39000 \mathrm{Pg} \mathrm{C}\left(1 \mathrm{Pg}=10^{15} \mathrm{~g}\right)$, and Geological carbon pool is estimated to be between 5000 and $10000 \mathrm{Pg}$. Soil and biotic (terrestrial ecosystems) include approximately $2500 \mathrm{Pg}$, and atmosphere includes $800 \mathrm{Pg} \mathrm{C}$. Soil organic carbon and inorganic carbon play important roles in global carbon cycle (Raich and Schlesinger, 1992; Janzen, 2004). Although there have been adequate information and studies on organic carbon stocks in the soils, there are no adequate studies and information on inorganic carbon stocks.

The largest of terrestrial carbon pools is soils, and the amount of carbon is three fold of the vegetation, and two fold of atmosphere. It has been considered that there is $1580 \mathrm{Pg} \mathrm{C}$ in $1 \mathrm{~m}$ depth of the soils (Houghton, 2007), and $2500 \mathrm{Pg} \mathrm{C}$ under the 2 $\mathrm{m}$ depth (Amundson, 2001). It has also been expressed that vegetation areas include $610 \mathrm{Pg} \mathrm{C}$ (Houghton, 2007) and the atmosphere includes $800 \mathrm{Pg} \mathrm{C}$ (Houghton, 2007). It was also stated that the carbon under $1 \mathrm{~m}$ depth of the soils was more in inorganic form (Janzen, 2004).

As another result of global warming and climate change, it has been suggested that drought at critical dimensions will be experienced in some regions of the world and vegetative production design will significantly change, correspondingly. Cultivation of medicinal and aromatic plants picked widely from the natural flora in Turkey and considered as alternative to the field crops especially in dry farming lands has become prominent (Yaldiz and Sekeroglu, 2013).

Although the studies carried out upon carbon concentrations of the surface soils are limited, such studies have recently increased a bit more. Schwendenmann et al. (2007) determined surface carbon stocks of the soils under different cultivation (forest, weeded areas, meadows, and wooded areas) conditions as $2.24,1.56,1.59$ and $2.94 \mathrm{~kg} \mathrm{C} \mathrm{m}^{-2}$, respectively. In their study carried out in Sirnak district in 2016 upon the surface carbon concentrations of the soils, Sakin et al. (2016) determined surface carbon concentrations of the soils as $1.22-2.79 \mathrm{~kg} \mathrm{~m}^{-2}$, and inorganic carbon amount as $1.08-40.36 \mathrm{~kg} \mathrm{~m}^{-2}$. In their study upon specifying the surface carbon concentrations of the soils in Adiyaman district, Sakin (2016) determined soil organic carbon concentrations as $0.88-3.06 \mathrm{~kg} \mathrm{~m}^{-2}$, and inorganic carbon concentrations as $0.32-26.40 \mathrm{~kg} \mathrm{~m}^{-2}$.

The purpose of this study was to compare surface carbon amounts, certain soil parameters and nutrients of the soils in habitats of medicinal and aromatic plants cultivated in Kahta district of Adıyaman province. 


\section{Materials and Methods}

\section{Material}

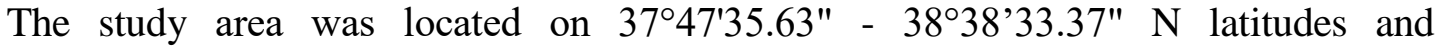
$37^{\circ} 49^{\prime} 52.54^{\prime \prime}-38^{\circ} 37^{\prime} 25.7231^{\prime \prime}$ E longitudes in Kahta district that is $40 \mathrm{~km}$ away from the Adiyaman. Elevation from sea level of the study area varied between 618 and $695 \mathrm{~m}$ (Figure 1). According to 35-year meteorological data, annual average temperature level of Kahta was $17.4^{\circ} \mathrm{C}$. Annual precipitation average was $504.7 \mathrm{~mm}$ (Anonymous, 2016a). According to Soil Taxonomy (Soil Survey Staff, 1975), soil moisture regime of the study area was xeric, and soil temperature regime was classified as mesic (KHGM, 1997).

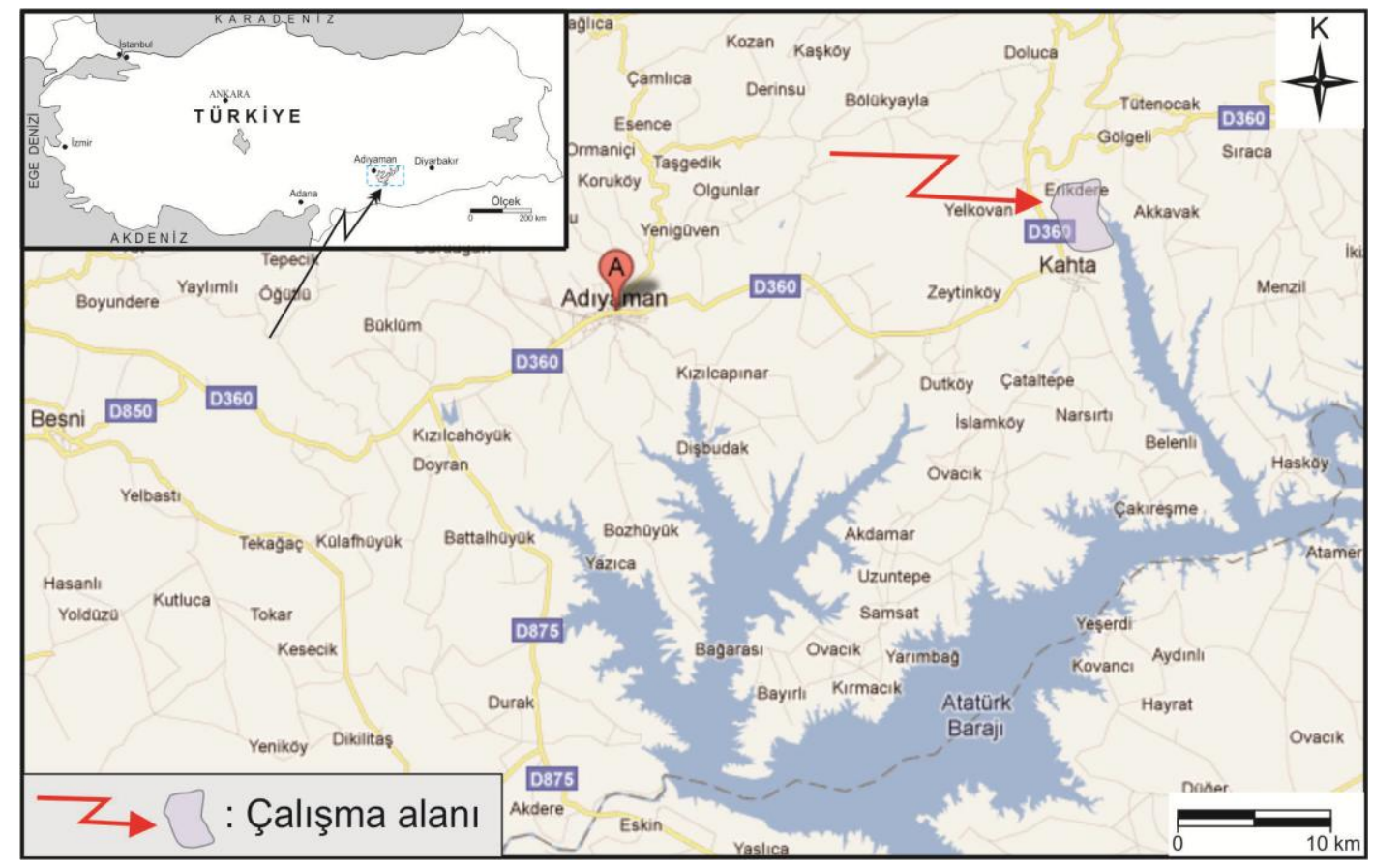

Figure 1. Location of the study area

Agriculture is engaged on totally 565.005 decare (da) areas all around AdiyamanKahta. Field agriculture and horticulture (vegetable and fruits) are held on 47.539 da of this area under irrigated conditions, and field agriculture and horticulture are held on 515.990 da of the area under dry farming conditions. 34.942 da of the area that could not be used for the agriculture has been used as the pasture area. In terms of field crops; wheat, cotton, tobacco and corn crop alternation has been used under irrigated conditions, and wheat, barley, lentil and chickpea crop alternation has been used under dry field conditions. Almond, pomegranate and walnut have recently been included among the prominent plant types in the studies carried out in horticulture (Anonymous, 2016b).

\section{Methods}

According to the samplings in the application area (Soil Survey Division Staff, 1993), some physical and chemical analyses, macro and micro nutrients of the soils and carbon concentrations of the surface soils were obtained from 60 disturbed soil samples (from 10 different points for each plant) of three different medicinal and aromatic plants 
(Rosmarinus officinalis, Salvia officinalis, Origanum onites) taken from two different soil depths $(0-30$ and 30-60 cm) in Adiyaman-Kahta district. Texture of the collected soil samples was determined using by hydrometer method (Bouyoucus, 1951). Soil reaction $(\mathrm{pH})$ was measured with $\mathrm{pH}$ meter (Richard, 1954) in saturated soil paste; and Electrical Conductivity (EC) was measured using electrical conductivity (Richards, 1954) in saturated soil paste. The calcareous content was determined with $10 \% \mathrm{HCI}$ using Scheibler Calcimeter (Allison and Moodie, 1965). Organic carbon content of the soils was determined according to wet decomposition method (Walkley, 1947), and nitrogen content of the soils was determined according to Kjeldahl (1983) method. Potassium contents were specified according to ammonium acetate method as reported by Jackson (1962), and K amount that permeated into the solution was specified using atomic absorption spectrophotometer (AAS). Phosphorous contents were colometrically determined in spectrophotometer according to the method suggested by Olsen et al. (1954). The relationship between some physic-chemical properties of the soil samples and some useful nutrients were determined using SPSS 9.0 package software.

In this study, bulk density (BD) of the soil samples was calculated according to the inequality suggested by Sakin et al. (2011) as mentioned below (Eq. 1). Surface organic carbon density of the soils was calculated according to Equation 2, and carbon stocks were calculated using Equation 3. Surface inorganic carbon (SIC) density was determined according to Equation 4, and SIC density was specified using Equation 5.

$$
\begin{aligned}
& \mathrm{BD}=19.167-\mathrm{SOM} / 11.7 \\
& \mathrm{SOCd}=\mathrm{BDi} * \mathrm{SOCi}^{*} \mathrm{Di}
\end{aligned}
$$

$\mathrm{SOCs}=\mathrm{SOCd} * \mathrm{~A}$

$\mathrm{SICd}=\mathrm{BDi}^{*} \mathrm{Di}^{*}\left(\mathrm{SICi}^{*} 0.12\right)$

$$
\mathrm{SICs}=\mathrm{SICd}^{*} \mathrm{~A}
$$

BD, bulk density $\left(\mathrm{g} \mathrm{cm}^{-3}\right)$; SOM, soil organic matter $(\%)$; SOCd, soil organic carbon density $\left(\mathrm{kg} \mathrm{m}^{-2}\right)$; SICd, soil inorganic carbon density $\left(\mathrm{kg} \mathrm{m}^{-2}\right)$; $\mathrm{SOCi}$, soil organic carbon (\%); SICi, soil inorganic carbon (\%); Di, depth (cm); SOCs, soil organic carbon stocks (Tg); SICs, soil inorganic carbon stocks (Tg); A, area $\left(\mathrm{m}^{2}\right)$.

\section{Results and Discussions}

Descriptive statistical values of the soils taken from the study area are presented in Table 1. According to this, minimum and maximum values of the texture fractions of the soils (sand, silt, clay) varied between $29.29-55.56 \%, 12.12-36.36 \%$ and $22.22-$ $52.53 \%$, respectively (Table 1). The soils with high clay amount were generally terrarossa smectite, illite and kaolinite content soils that formed as result of weathering and 
degradation of carbonate rocks (KHGM, 1990). Moreover, contribution of smectite and illite rich Sahara origin dusts was also remarkable (Kapur et al., 1998). This accommodated with some soil serials in the studies carried out in the similar region by KHGM $(1996 ; 1997)$ previously.

Table 1. Descriptive statistical values of soils

\begin{tabular}{|c|c|c|c|c|c|}
\hline Soil parameters & Minimum & Maximum & Mean & Std. Error & Std. Deviation \\
\hline Sand $(\%)$ & 29.29 & 55.56 & 42.01 & 1.34 & 6.01 \\
\hline Silt (\%) & 12.12 & 36.36 & 20.72 & 1.19 & 5.32 \\
\hline Clay $(\%)$ & 22.22 & 52.53 & 37.27 & 1.32 & 5.93 \\
\hline Soil reaction $(\mathrm{pH})$ & 6.91 & 8.30 & 7.67 & 0.11 & 0.49 \\
\hline Electrical conductivity (EC) & 0.08 & 0.45 & 0.31 & 0.09 & 0.08 \\
\hline Organic matter (OM, \%) & 1.27 & 2.85 & 2.13 & 0.09 & 0.41 \\
\hline Organic carbon (OC, \%) & 0.77 & 1.65 & 1.23 & 0.05 & 0.23 \\
\hline Calcareous $\left(\mathrm{CaCO}_{3}, \%\right)$ & 0.75 & 1.46 & 1.11 & 0.07 & 0.40 \\
\hline Total nitrogen $(\mathrm{N}, \%)$ & 0.04 & 0.13 & 0.07 & 0.005 & 0.02 \\
\hline $\mathrm{P}_{2} \mathrm{O}_{5}\left(\mathrm{~kg} \mathrm{da}^{-1}\right)$ & 1.35 & 25.70 & 4.28 & 1.53 & 6.84 \\
\hline $\mathrm{K}_{2} \mathrm{O}\left(\mathrm{kg} \mathrm{da}^{-1}\right)$ & 125.00 & 228.06 & 157.39 & 5.85 & 26.18 \\
\hline $\mathrm{Fe}\left(\mathrm{mg} \mathrm{kg}^{-1}\right)$ & 2.10 & 9.22 & 5.31 & 0.59 & 2.67 \\
\hline $\mathrm{Cu}\left(\mathrm{mg} \mathrm{kg}^{-1}\right)$ & 1.12 & 3.45 & 2.13 & 0.14 & 0.66 \\
\hline $\mathrm{Zn}\left(\mathrm{mg} \mathrm{kg}^{-1}\right)$ & 0.39 & 0.77 & 0.54 & 0.02 & 0.10 \\
\hline $\operatorname{Mn}\left(\mathrm{mg} \mathrm{kg}^{-1}\right)$ & 5.31 & 9.18 & 5.98 & 0.22 & 1.01 \\
\hline
\end{tabular}

Soil reactions of the soils varied between 6.91-8.30, and the average value was 7.67 (Table 1). Aforementioned values were evaluated as "low alkali" by Ulgen and Yurtsever (1995). Similar results were also determined in the studies carried out by KHGM (1990; 1996; 1997), Tazebay and Saltali (2011), and Celik et al. (2015). Electrical conductivities of the soils varied between (EC) $0.08-0.45 \mathrm{dS} \mathrm{m}^{-1}$, and these values were classified as "non salin" according to Maas (1986). According to these values, the soils had no salinity problem. Obtained results were similar to ones in the studies of Seyrek et al. (1999) and KHGM (1997).

Calcareous content of the soils in the study area was determined between $0.75 \%$ and $1.46 \%$ (Table 1). Calcareous contents of the study area were considered to differ depending upon marn and conglomerate content parent material and other reasons. Mean of the analysis results was determined as $1.11 \%$, and according to the classification results (Ulgen and Yurtsever, 1995), the soils were determined as "calcareous." Similar results were also found in the studies carried out by KHGM (1990, 1996, 1997), Sabbag and Akca (2015), and Ozgor (2015) in the same area. 
Organic carbon contents of the soils were determined to vary between $0.77 \%$ and $1.65 \%$ (Table 1). The average results were evaluated at "low" level in the classification (Ulgen and Yurtsever, 1995). The region's having an arid and semi-arid climate caused organic substance level to be low (Sakin, 2016). Increasing the organic matter level of the soils in the investigation area was remarkable in terms of productivity and quality of the plants cultivated in the agricultural applications to be held in the area. Organic matter levels were parallel with the findings in the studies carried out by Sabbag and Akca (2015), and Ozgor (2015).

Phosphorus and potassium levels taken from the soil were determined as 1.35-25.70 $\mathrm{kg} \mathrm{P}_{2} \mathrm{O}_{5} \mathrm{da}^{-1}$ and 125.00-228.06 $\mathrm{kg} \mathrm{K}_{2} \mathrm{O} \mathrm{da}^{-1}$, respectively (Table 1). Determined mean results were evaluated at the level of "low" according to the classification (Ulgen and Yurtsever, 1995). Obtained results were parallel with the findings of the studies carried out by KHGM (1997), Saracoglu et al. (2014), and Ates and Turan (2015). Available potassium values of the soils in the research area were determined as $125.00-228.06 \mathrm{~kg}$ $\mathrm{K}_{2} \mathrm{O} \mathrm{da}^{-1}$. According to the classification of Ulgen and Yurtsever (1995), the level was determined to be at a "low" level. According to these results, high potassium content of the soils provided significant advantages in terms of plant growing and production quality. The results obtained from the studies carried out in the region previously proved that the potassium levels were high (KHGM, 1990, 1996, 1997; Tazebay and Saltali, 2011; Celik et al., 2015; Ozgor, 2015). Available P contents of the soils were determined to be low (Havlin et al., 2005), and K contents were specified to be high (Eyupoglu, 1999). High illite content of the soils was considered to cause high K content.

Nitrogen contents of the soils in the research area varied between $0.04 \%$ and $0.13 \%$ (Table 1). Determined mean nitrogen levels were determined at "very low" level according to the competence classification of FAO (1990). Similar results were determined by KHGM (1997), and Cimrin and Boysan (2006). Finding the nitrogen contents at a low level in majority of the research soils was considered to be explained through the sand content in the textural structure and inadequacy of the organic substances in the soil.

Iron $(\mathrm{Fe})$ as one of the available micro elements varied between $(\mathrm{Fe}) 2.10-9.22 \mathrm{mg}$ $\mathrm{kg}^{-1}$, copper $(\mathrm{Cu})$ varied between $1.12-3.45 \mathrm{mg} \mathrm{kg}^{-1}$, zinc varied between $(\mathrm{Zn})$ 0.39-0.77 $\mathrm{mg} \mathrm{kg}{ }^{-1}$ and manganese $(\mathrm{Mn})$ varied between 5.31-9.18 $\mathrm{mg} \mathrm{kg}^{-1}$ (Table 1). Iron (Fe) as one of the available micro elements was determined to be $2.10-9.22 \mathrm{mg} \mathrm{kg}^{-1}$. According to the limit values of Lindsay and Norvell (1978), the value was determined to be "low" in areas with iron deficiency. Results of our study were similar to the results of several researches carried out previously (KHGM, 1997; Çimrin and Boysan, 2006; Eyupoglu et al., 1996). Copper $(\mathrm{Cu})$ content in the study area was determined to vary between 1.12 and $3.24 \mathrm{mg} \mathrm{kg}^{-1}$. According to the limit values reported by Lindsay and Norvell (1978), all soils were found to be at "adequate" level in terms of available copper $(>0.2$ $\mathrm{ppm})$. There was no need for the copper-content prepared fertilizers.

Zinc $(\mathrm{Zn})$ contents of the research soils were determined to vary between 0.39-0.77 $\mathrm{mg} \mathrm{kg}$ ", and average values were found to be at "low" level according to FAO (1990) (Table 1). In the area, $\mathrm{Zn}$ was determined to be at an inadequate level as result of the study carried out by Kizilgoz et al. (1999). The reason for zinc deficiency was considered to be arisen from high level lime content in the soils of the area. The manganese $(\mathrm{Mn})$ content in the soil samples of the research area varied between 5.31$9.18 \mathrm{mg} \mathrm{kg}^{-1}$. The manganese level in all samples was founded to be above the critical 
level reported by Lindsay and Norvell (1978). Obtained results were parallel with the findings of the studies carried out by Cimrin and Boysan (2006), Saracoglu et al. (2014), and Ozgor (2015).

The correlation values between the soil parameters of the soils taken from the district were presented in Table 2. According to this, organic carbon content of the soils was found to have an insignificant negative relationship with sand\% as one of the particle fractions of the soils and have non-significant positive relationship with silt\% and clay\% ( $>0.05$ ). Clayed structure (heavy textured) of the regions soils provided the soils to be more resistant against decomposition and degradation protecting SOC. Due to this property, carbon contents of the soils were considered to be more than estimated (Sakin, 2013). Silicate clay mineral types were expressed to be one of the most significant factors affecting the SOM dynamics (Paul, 1984). Silicate clays were clearly noticed to protect humus and created complexes with the organic substances in several researches (Anderson and Paul, 1984). Deposition velocity of the carbon in the soil was not constant, and depended upon the dynamics between the terrain features, vegetation, climate, and in-soil water level. Deposition of SOM has been maintained since the beginning of soil formation, and deposition velocities differ according to the conditions (Milne et al., 2007). Surface area as one of the clay minerals soil properties affects parameters such as CEC and change density, and these factors affect degradation rate of the organic substances (Kumar and Babel, 2011)

A significant correlation was found between organic carbon content and soil reaction $(\mathrm{r}=-0.546, \mathrm{p}<0.05)$, and very significant negative correlation was found between carbon content and EC $(r=-0.563, \mathrm{p}<0.01)$. Whereas a significant positive relationship was specified between soil carbon content and $\mathrm{Zn}$ as one of the available micro elements $(\mathrm{r}=$ $0.472, \mathrm{p}<0.05)$, no correlation was determined between soil carbon content and other elements ( $p>0.05)$. Yadav (2008) mentioned that there was a positive relationship between useful nutrients $(\mathrm{Cu}, \mathrm{Fe}, \mathrm{Mn}, \mathrm{Zn}$ and $\mathrm{B})$ and organic matter, and a negative correlation between $\mathrm{pH}$ and $\mathrm{CaCO}_{3}$. In their study, Yadav and Meena (2009) stated that as the clay amount $\left(\mathrm{r}=+0.597^{*}\right)$, organic matter amount $\left(\mathrm{r}=+0.896^{* *}\right)$, EC $(\mathrm{r}=$ $\left.+0.305^{*}\right)$, and CEC $(\mathrm{r}=+0.527 * *)$ increased, useful $\mathrm{Zn}$ amount decreased significantly. Sidhu and Sharma (2010) reported in their study that whereas useful nutrients $(\mathrm{Cu}, \mathrm{Fe}$, $\mathrm{Mn}, \mathrm{Zn}$, and B) increased as the organic matter amount increased; useful nutrients decreased as $\mathrm{pH}$, sand and $\mathrm{CaCO}_{3}$ increased.

$\mathrm{Cu}, \mathrm{Fe}, \mathrm{Mn}, \mathrm{Zn}, \mathrm{B}, \mathrm{P}$ and $\mathrm{K}$ as micro and macro nutrients had positive correlation with $\mathrm{OM}$ as one of the soil properties, and had a negative correlation with clay, $\mathrm{pH}$ and $\mathrm{CaCO}_{3}$ content (Table 2). As clay, silt and $\mathrm{CEC}$ increased, total micro nutrients $(\mathrm{Cu}, \mathrm{Fe}$, $\mathrm{Mn}, \mathrm{Zn}$, and $\mathrm{B}$ ) increased, as well, and as $\mathrm{pH}$, sand and $\mathrm{CaCO}_{3}$ content increased, total micro nutrients decreased. Increase at organic matter caused increase of micro and macro elements at a significant level (Sakin and Munis, 2016).

Organic carbon contents of the soils were determined to have significant relationship with available $\mathrm{P}(\mathrm{r}=0.543, \mathrm{p}<0.05)$ and very significant relationship with total $\mathrm{N}$ $(\mathrm{r}=0.85, \mathrm{p}<0.01)$; no correlation was determined with available $\mathrm{K}(\mathrm{p}>0.05)$. No statistical relationship was specified between calcareous content and carbon content of the soils $(\mathrm{p}>0.05)$. 
Table 2. Correlation between soil parameters

\begin{tabular}{|c|c|c|c|c|c|c|c|c|c|c|c|c|c|}
\hline Soil parameters & $\begin{array}{c}\text { Sand } \\
(\%)\end{array}$ & $\begin{array}{l}\text { Silt } \\
(\%)\end{array}$ & $\begin{array}{l}\text { Clay } \\
(\%)\end{array}$ & $\begin{array}{c}\text { pH } \\
(1: 2.5)\end{array}$ & $\begin{array}{c}\text { EC } \\
\left(\mu \mathrm{S} \mathrm{cm}^{-1}\right)\end{array}$ & $\begin{array}{l}\text { OM } \\
(\%)\end{array}$ & OC $(\%)$ & $\mathrm{CaCO}_{3}(\%)$ & $\begin{array}{c}N \\
(\%)\end{array}$ & $\begin{array}{c}\mathbf{P}_{2} \mathrm{O}_{5} \\
\left(\mathrm{~kg} \mathrm{P}_{2} \mathrm{O}_{5} \mathrm{da}^{-1}\right)\end{array}$ & $\begin{array}{c}\mathrm{K}_{2} \mathrm{O} \\
\left(\mathrm{kg} \mathrm{K}_{2} \mathrm{O} \mathrm{da}^{-1}\right)\end{array}$ & $\begin{array}{c}\mathrm{Fe} \\
\left(\mathrm{mg} \mathrm{kg}^{-1}\right)\end{array}$ & $\begin{array}{c}\mathrm{Cu} \\
\left(\mathrm{mg} \mathrm{kg}^{-1}\right)\end{array}$ \\
\hline \multirow{2}{*}{ Silt (\%) } & $-0.458^{*}$ & & & & & & & & & & & & \\
\hline & 0.042 & & & & & & & & & & & & \\
\hline \multirow{2}{*}{ Clay (\%) } & $-0.602^{* *}$ & -0.433 & & & & & & & & & & & \\
\hline & 0.005 & 0.056 & & & & & & & & & & & \\
\hline \multirow{2}{*}{ Soil Reaction (pH) } & 0.077 & -0.323 & 0.215 & & & & & & & & & & \\
\hline & 0.748 & 0.165 & 0.363 & & & & & & & & & & \\
\hline \multirow{2}{*}{ Electrical Conductivity (EC) } & 0.159 & -0.315 & 0.124 & $0.963^{* *}$ & & & & & & & & & \\
\hline & 0.503 & 0.176 & 0.601 & 0.000 & & & & & & & & & \\
\hline \multirow{2}{*}{ Organic matter $(\mathrm{OM})$} & -0.299 & 0.205 & 0.116 & $-0.493^{*}$ & $-0.530^{*}$ & & & & & & & & \\
\hline & 0.200 & 0.385 & 0.627 & 0.027 & 0.016 & & & & & & & & \\
\hline \multirow{2}{*}{ Organic carbon (OC) } & -0.325 & 0.190 & 0.156 & $-0.546^{*}$ & $-0.563^{* *}$ & $0.978^{* *}$ & & & & & & & \\
\hline & 0.161 & 0.422 & 0.511 & 0.013 & 0.010 & 0.000 & & & & & & & \\
\hline \multirow{2}{*}{ Calcareous content $\left(\mathrm{CaCO}_{3}\right)$} & 0.068 & 0.122 & -0.176 & $0.465^{*}$ & $0.546^{*}$ & -0.267 & -0.257 & & & & & & \\
\hline & 0.776 & 0.608 & 0.457 & 0.039 & 0.013 & 0.254 & 0.274 & & & & & & \\
\hline \multirow{2}{*}{ Total nitrogen $(\mathrm{N})$} & -0.096 & 0.111 & 0.000 & 0.361 & $0.448^{*}$ & 0.079 & $0.850^{* *}$ & 0.242 & & & & & \\
\hline & 0.687 & 0.642 & 0.999 & 0.118 & 0.048 & 0.742 & 0.000 & 0.304 & & & & & \\
\hline \multirow{2}{*}{ Phosphoruos $\left(\mathrm{P}_{2} \mathrm{O}_{5}\right)$} & 0.004 & 0.113 & -0.109 & $-0.632^{* *}$ & $-0.664^{* *}$ & $0.529^{*}$ & $0.543^{*}$ & -0.435 & -0.356 & & & & \\
\hline & 0.986 & 0.636 & 0.647 & 0.003 & 0.001 & 0.016 & 0.013 & 0.055 & 0.123 & & & & \\
\hline \multirow{2}{*}{ Potassium $\left(\mathrm{K}_{2} \mathrm{O}\right)$} & 0.218 & -0.064 & -0.165 & -0.225 & -0.249 & 0.099 & 0.106 & -0.137 & -0.253 & $0.557^{*}$ & & & \\
\hline & 0.355 & 0.787 & 0.487 & 0.341 & 0.291 & 0.679 & 0.656 & 0.565 & 0.283 & 0.011 & & & \\
\hline \multirow{2}{*}{ Iron $(\mathrm{Fe})$} & 0.196 & -0.366 & 0.132 & $0.736^{* *}$ & $0.745^{* *}$ & -0.248 & -0.324 & 0.345 & 0.119 & $-0.513^{*}$ & -0.341 & & \\
\hline & 0.406 & 0.113 & 0.580 & 0.000 & 0.000 & 0.293 & 0.163 & 0.136 & 0.616 & 0.021 & 0.141 & & \\
\hline \multirow{2}{*}{ Copper $(\mathrm{Cu})$} & 0.148 & -0.350 & 0.166 & 0.189 & 0.282 & -0.115 & -0.092 & 0.271 & -0.083 & -0.267 & -0.356 & 0.397 & \\
\hline & 0.534 & 0.130 & 0.484 & 0.424 & 0.228 & 0.629 & 0.700 & 0.248 & 0.727 & 0.255 & 0.123 & 0.083 & \\
\hline \multirow{2}{*}{ Zinc (Zn) } & -0.153 & 0.013 & 0.142 & -0.230 & -0.265 & $0.452^{*}$ & $0.472^{*}$ & -0.074 & -0.223 & 0.221 & 0.366 & -0.150 & 0.035 \\
\hline & 0.521 & 0.955 & 0.550 & 0.328 & 0.258 & 0.045 & 0.036 & 0.756 & 0.346 & 0.349 & 0.113 & 0.528 & 0.884 \\
\hline \multirow{2}{*}{ Manganese (Mn) } & -0.079 & 0.193 & -0.094 & $-0.669^{* *}$ & $-0.720^{* *}$ & 0.288 & 0.325 & -0.335 & -0.214 & 0.205 & -0.035 & $-0.478^{*}$ & -0.140 \\
\hline & 0.739 & 0.415 & 0.694 & 0.001 & 0.000 & 0.218 & 0.162 & 0.149 & 0.366 & 0.387 & 0.884 & 0.033 & 0.556 \\
\hline
\end{tabular}

$* \mathrm{p}<0,05$ 
Surface organic carbon density of the soils was between $2.42-5.05 \mathrm{~kg} \mathrm{~m}^{-2}$, and the mean was $3.76 \mathrm{~kg} \mathrm{C} \mathrm{m}^{-2}$. In the studies carried out in similar areas, organic carbon concentrations of the surface soils were determined as $0.88-3.06 \mathrm{~kg} \mathrm{~m}^{-2}$ (Sakin, 2016), 1.22-2.97 $\mathrm{kg} \mathrm{m}^{-2}$ (Sakin et al., 2016), and 1.6-4.36 $\mathrm{kg} \mathrm{m}^{-2}$ (Sakin et al., 2014). When the studies carried out in the area were reviewed, it was revealed that similar results were obtained, and all these results supported the findings of our study. These three regions had similar climate and soil properties, and the little differences among these three could be arisen from climatic parameters, soil cultivation techniques, penetration of organic carbon into soil, and soil management. According to the studies of Sakin and Munis (2016), low organic carbon content of the soils in the region could be caused by the region's having an arid and semi-arid climate, high oxidation rate and low vegetation.

It is necessary to fully understand the global carbon cycle in order to know organic and inorganic carbon dynamics and importance of soils better. This cycle is important in order to evaluate the carbon storage and emission between atmosphere, biosphere, and pedosphere (Lal et al., 2000). It has been known that southern soils of Turkey include organic and inorganic carbon. Although organic carbon storage amount of the soils is known more or less, the information on inorganic carbon amount has been known to be limited. Because the area was arid and semi-arid, carbon segregation was low. In such areas, it is necessary to increase biomass level and atmospheric $\mathrm{CO}_{2}$ amount besides the irrigation.

Various factors have effects upon the organic carbon amount in the soil. These are vegetation, soil, soil topography, parent material, climate, biological beings and time, respectively (Entry et al., 2004). Organic carbon has significant effects upon the physical, chemical and biological properties of the soils. Changing environmental conditions are possible to be efficient upon the organic carbon content and amount of the soils.

Inorganic carbon concentrations of the soils vary between $2.75-5.36 \mathrm{~kg} \mathrm{~m}^{-2}$, and the average is $4.08 \mathrm{~kg} \mathrm{~m}^{-2}$. In their study they carried out in Sirnak area, Sakin et al. (2016) determined inorganic carbon densities of the soils as $1.08-40.63 \mathrm{~kg} \mathrm{~m}^{-2}$; in their study they carried out in Diyarbakir area, Sakin et al. (2014) determined SIC as 0.0$6.0 \mathrm{~kg} \mathrm{~m}^{-2}$, and in their study in Adiyaman area, Sakin (2016) determined the value as $0.32-26.40 \mathrm{~kg} \mathrm{~m}^{-2}$. Soils having different lime contents caused inorganic carbon concentrations to be different.

The soils in the area are generally formed as result of weathering and degradation of carbonate rocks (KHGM, 1990). Lime contents of the soils differ depending upon the marl and conglomerate-content parent material and other reasons. Redundancy of the lime contents caused inorganic carbon values to be much.

\section{Conclusion}

The soils in the study area were determined to have no drainage problem, and have a clay and clay-loam structure, $\mathrm{pH}$ low alkali, saline, low lime content and medium level organic matter content. In terms of the nutrients, total nitrogen was determined to be at a very low level, phosphor and zinc $(0.54 \mathrm{ppm})$ at low level, potassium and iron at high level, and copper and manganese at adequate levels. Whereas the organic carbon concentrations of the soils varied between $2.42-5.05 \mathrm{~kg} \mathrm{~m}^{-2}$, and the average was 3.76 $\mathrm{kg} \mathrm{C} \mathrm{m}{ }^{-2}$, inorganic carbon concentrations of the soils varied between $2.75-5.36 \mathrm{~kg} \mathrm{~m}^{-2}$, and the average was $4.08 \mathrm{~kg} \mathrm{~m}^{-2}$. 
The highest organic and inorganic carbon concentrations in the soils of the study area were determined on the area where sage (Salvia officinalis) plant was grown. Because organic carbon content and lime content of the soils in the area were low, organic and inorganic carbon stocks and concentrations were determined to be at low level. Because the climate was arid and semi-arid in the study area, this limited the increasing of plant biomass amount. Low plant biomass level causes organic carbon amounts of the soils to be low. Furthermore, penetration of organic wastes into the soils decreases as result of burning majority of the plant biomass content, and picking it as animal feed or fuel. For that reason, carbon contents in the soils remain at a low level. In order to increase the level of soil quality and provide the quality sustainability, it is essential to protect and increase organic carbon level.

\section{REFERENCES}

[1] Allison, L.E., Moodie. C.D. (1965): Carbonate. - In: Black, C. A., et al (eds.) Metods of Soils Analysis. Part 2. Agronomy 9 (1), Am. Soc. of Argon., Inc., Madison, pp. 1379 1400, Wisconson U.S.A.

[2] Amundson, R. (2001): The Carbon Budget in Soils. - Annu. Rev. Earth Planet. Sci. 29:535-562.

[3] Anderson, D.W., Paul, E.A. (1984): Organo - Mineral Complexes and Their Study by Radiocarbon Dating. - Soil Sci. Soc. Am. J. 48: 298 - 301.

[4] Anonymous (2016a): General Directorate of Meteorology, Ankara.

[5] Anonymous (2016b): Adiyaman Governorship of Food, Agriculture and Livestock Directorate, 2015 Annual Briefing, Adiyaman.

[6] Ateş, K., Turan, V. (2015): Some Soil Characteristics and the Fertility Status of Agricultural Soils in Bingöl Central District. - Journal of Agricultural Research in Turkey 2: 108-113.

[7] Bouyoucus, G. J. (1951): A Recalibration of The Hydrometer for Making Mechanical Analysis of Soils. - Agron. Jour. 3: 434 - 438.

[8] Çelik, A., Akça, E., Yıldırım, Y., Büyük, G., Kapur, S. (2015): The Clay Mineralogy of Clay Beds in Non-arable Soils in Adiyaman Region: Their Utilization Potential as Brick Ceramic Raw Material. - $16^{\text {th }}$ National Clay Symposıum, University of Çanakkale Onsekiz Mart Publications: 127 Symposıum Book:128-138, Çanakkale.

[9] Çimrin, K. M., Boysan, S. (2006): Nutrient Elements of Van Soil Agricultural Soils and Their Relations with Some Soil Properties. - University of Yüzüncü Y1l, Agricultural Faculty Journal of Agricultural Sciences 16(2): 105-111.

[10] Entry, J.A., Fuhrmann, J.J., Sojka, R.E., Shewmaker, G.E. (2004): Influence of Irrigated Agriculture on Soil Carbon and Microbial Community Structure. - Environ.Mgmt. 33: 363-373.

[11] Eyüpoğlu, F. (1999): Efficiency Status of Turkish Soils. KHGM Soil and Fertilizer Research Institute Publication Technical Publications, T-67, 220: 1-122, Ankara.

[12] Eyüpoğlu, F., Kurucu, N., Talaz, S. (1996): General Situation of Turkey Soil in terms of Some Micro Elements. - Soil Fertilizer Research Institute Publications, Ankara.

[13] FAO. (1990): Micronutrient, Assesment at the Country Level, an Intemational Study. FAO Soils Bulletin, 63. Rome.

[14] Havlin, J. L., Beaton, J. D., Tisdale, S. L., and Nelson, W. L. (2005): Soil Fertility and Fertilizers (7th ed.). ISBN: 0-13-027824-6 Pearson Education Limited USA; 1-515.

[15] Houghton, R. A. (2007): Balancing the Global Carbon Budget. - Annual Review of Earth and Planetary Sciences 35: 313 - 347.

[16] Jackson, M.L. (1962): Soil Chemical Analsis. - Prentice Hall. Inc.183. 
[17] Janzen, H. H. (2004): Carbon Cycling in Earth System - a Soil Science Perspective. Agriculture, Ecosystem and Environment 104: 399 - 417.

[18] Kapur, S., Saydam, C., Akça, E., Çavuşgil, V.S., Karaman, C., Atalay, İ. and Özsoy, T. (1998): Carbonate Pools in Soils of The Mediterranean: A Case Study From Anatolia. In: Lal, R., Kimble, J.M., Stewart, B.A. (eds.) Global Climate Change and Pedogenic Carbonates. Lewis Publishers. pp. 187-212.

[19] KHGM. (1990): Adıyaman Çamgazi Plain Irrigation Project Site Detailed Basic Soil Investigations. General Directorate of Rural Services Soil Survey Branch, Ankara, 212.

[20] KHGM. (1996): Adıyaman-Besni, Keysun and Kizılın Plain Irrigation Project Site Detailed Soil Studies, General Directorate of Rural Services Soil Survey Branch, Ankara, 168.

[21] KHGM. (1997): Adıyaman Kâhta Plain Irrigation Project Site Detailed Soil Studies, General Directorate of Rural Services Soil Survey Branch, Ankara, 250.

[22] Kizılgoz, İ., Kızılkaya, R., Acar, İ., Seyrek, A., Kaptan, H. (1999): A Research on the Determination of the Productivity Levels of Soils Grown Pistacia Vera L. in Şanlıurfa Region. - GAP I. Agriculture Congress, Şanliurfa, 26-28 May 1999. II:987-994.

[23] Kjeldahl, J. (1983): Analaysis of Nitrogen. - Z. Anal. Chem. 22:366-382.

[24] Kumar, B., Babel, A.L., (2011): Available Micronutrient Status and Their Relationship with Soil Properties of Jhunjhunu Tehsil, District Jhunjhunu, Rajasthan, India. - Journal of Agricultural Science 3(2): 97-106.

[25] Lal, R., Ahmadi, M., Bajracharya, R.M. (2000): Erosional İmpacts on Soil Properties and Corn Yield on Alfisols in Central Ohio. - Land Degrad Develop 11:575-585.

[26] Lindsay, W.L., Norvell, W.A. (1978): Development of a DTPA Soil Test for Zinc, İron, Manganese and Copper. - Soil Sci., Soc. Am. J. 42:421-428.

[27] Maas, E. V. (1986): Salt Tolerance of Plants. - Applied Agricultural Research 1: 12-26.

[28] Milne, E., Paustian, K., Easter, M., Sessay, M., Al - Adamat, R., Batjes, N. H., Bernoux, M., Bhattacharyya, T., Cerri, C.C., Eduardo, C., Cerri, P., Coleman, K., Falloon, P., Feller, C., Gicheru, P., Kamoni, P., Killian, K., Pal, D.K., Powlson, D.S., Williams, D.S., Rawajfih, R. (2007): An Increased Understanding of Soil Organic Carbon Stocks and Changes in Non - Temperate Areas: National and Global Implications. - Agriculture, Ecosystems and Environment 122: $125-136$.

[29] Olsen, S.R., Cole, V., Watanabe, F.S., Dean, L.A. (1954): Estimation of Available Phosphorus in Soils by Extraction with Sodium Bicarbonate, USDA Circular No: 939, Washington DC.

[30] Ozgor, O. (2015): Adiyaman-Gölbaş1 Soil of Some Physical, Chemical and Mineralogical Characteristics, Master Thesis. - University of Harran, Institute of Natural and Applied Sciences, Şanliurfa.

[31] Paul, E.A. (1984): Dynamic of Organic Matter in Soils. - J. Plant Soil. 76: 275 - 285.

[32] Raich, J. W., Schlesinger, W. H. (1992): The Global Carbondioxide in Soil Respiration and Its Relation on Ship to Vegetation and Climate. - Tellus 44 B: 81 - 99.

[33] Richards, L.A. (1954): Diagnosis and İmprovements Saline and Alkali Soils. - U.S. Dept. Agr. Handbook 60.

[34] Sabbag, Ç., Akça, E. (2015): Nutrient and Soil Properties of Adryaman Local Pepper. GAP VII. Agriculture Congress, Present Paper. 28 April-1 May 2015: 1-4, Şanliurfa.

[35] Sakin, E. (2013): Carbon Balance and Stocks in Soils of South-Eastern Region (SAR). Journal of Food, Agriculture \& Environment 11 (3\&4): 2186-2189.

[36] Sakin, E. (2016): Carbon Stocks of Adiyaman Province Surface Soils. - International Multidisciplinary Eurasian Congress, 11-13 July 2016, Odessa / Ukranıa (in press).

[37] Sakin, E., Deliboran, A., Tutar, E. (2011): Bulk Density of Harran Plain Soils in Relation to other Soil Properties. - African Journal of Agricultural Research 6 (7): 1750-1757.

[38] Sakin, E., Sakin, E.D., Seyrek, A. (2014): Carbon Stocks and Amounts of Diyarbakır Province Surface Soils. - Harran Journal of Agricultural and Food Science 18 (2): 1-7. 
[39] Sakin, E., Sakin, E.D., Seyrek, A. (2016): Carbon Stocks of Sirnak Province Surface Soils. - International Multidisciplinary Eurasian Congress, 11-13 July 2016, Odessa / Ukranıa (in press).

[40] Sakin, E., ve Munis, M.M. (2016): The Status of Available Nutrients Soil and Their Relationship with the Soil Properties In Southeastern Turkey. - Oxidation Communication 39 (1-I): 331-337.

[41] Saraçoğlu, M., Sürücü, A., Koşar, İ., Anlağan Taş, M., Aydoğdu, M., Kara, H. (2014): Determination of some soil characteristics and in the nutrient of the scope contents district Halfeti Şanlıurfa. - Journal of Soil Science and Plant Nutrition 2 (2): 38 - 45.

[42] Schlesinger,W. H., Andrews, J. F. (2000): Soil Respiration and the Global Carbon Cycle. - Biogeochemistry 48: 7 - 20.

[43] Schwendenmann, L., Pendall, E., Potvin, C. (2007): Surface soil organic carbon pools, mineralization and $\mathrm{CO}_{2}$ efflux rates under diferent land-use types in Central Panama. Environmental Science and Engineering, 107-129, DOI: 10.1007/978-3-540-30290-2_6.

[44] Seyrek, A., Kızılgöz, İ., Çullu, M.A., İnce, F. (1999): Heavy Metal Contents of SoilAffected Soils in Harran Plaster, GAP 1. Agriculture congress, 26-28 May, Şanliurfa.

[45] Sidhu, G.S., Sharma, B.D. (2010): Diethylenetriaminepentaacetic Acid-Extractable Micronutrients Status in Soil under a Rice-Wheat System and Their Relationship with Soil Properties in Different Agro-climatic Zones of Indo-Gangetic Plains of India. Communications in Soil Science and Plant Analysis 41(1): 29-51.

[46] Soil Survey Staff. (1975): Soil Taxonomy. A Basic System of Soil Classification for Making and Interpreting Soil Surveys. - USDA, A Soil Cons. Service, Apr, Handbook Number 436, 754.

[47] Soil Survey Staff. (1993): Soil Survey Manual. - USDA, Handbook Number: 18, USA.

[48] Tazebay, N., Saltal1, K. (2011): Evaluation of the soils of dry and irrigated agricultural fields in terms of efficiency in Adiyaman-Besni district. - Prof. Dr. Nuri Munsuz National Soil and Water Symposium, Ankara.

[49] U.S. Salinity Laboratory Staff. (1954): Diagnosis and Improvement of Saline and Alkali Soils. - USDA Agricultural Handbook Number 60.

[50] Ulgen, N., Yurtsever, N. (1995): Turkey Fertilizer and Fertilization Guide (4. Printing). T.C. Prime Ministry Village Services General Directorate Institute of Soil and Fertilizer Research Institute Publications, General Release Number: 209: T.66, 230, Ankara.

[51] Walkley, A. (1947): A Critical Examination of A Rapid Method For Determining Organic Carbon of Soils. - Soil Sci. 63: 251 - 263.

[52] Yadav, K.K. (2008): Micronutrient Status in Soils of Udaipur District of Rajasthan. Hydrology Journal 31 (3\&4): 26-39.

[53] Yadav, R.L., Meena, M.C. (2009): Available Micronutrients Status and Relationship With Soil Properties of Degana Soil Series of Rajasthan. - Journal of the Indian Society of Soil Science 57(1): 90-92.

[54] Yaldız, G., Şekeroğlu, N. (2013): The Importance of Medical and Aromatic Plants in Global Climate Change. - Turkish Journal of Scientific Reviews 6 (1): 85-88. 